\title{
The Comparative of Study Culpable Rights in Preliminary Investigation in Iran and Turkey
}

\author{
Mina Mehrvand ${ }^{1} \&$ Khalil Afandak ${ }^{2}$ \\ ${ }^{1}$ Department of Law, Islamic Azad University, Ilkhchi Branch, Ilkhchi, Iran \\ ${ }^{2}$ Department of Law, Islamic Azad University, Ahar Branch, Ahar, Iran \\ Correspondence: Mina Mehrvand, Department of Law, Islamic Azad University, Ilkhchi Branch, Ilkhchi, Iran. \\ E-mail: mi.mehrvand@gmail.com
}

Received: March 8, 2016 Accepted: March 28, 2016 Online Published: May 29, 2016

doi:10.5539/jpl.v9n4p65 URL: http://dx.doi.org/10.5539/jpl.v9n4p65

\begin{abstract}
The preliminary investigation to determine the fate of the victims and the defendants ' judicial rights of the victims and the criminal justice is of special importance. The preliminary investigation of the center of gravity of the interrogation of suspects. Considering the necessity of supporting the principle of presumed innocence and preserve human dignity in the hearing process, the main lines of the meanwhile defensive rights defendants at the stage of preliminary investigation determined. Examples of the rights of the defense and legal formalities and job maker Iran and Turkey in the interrogation system varied. However, what is the condition for this is that a fair hearing in accordance with the principles of this extension should be anticipated and mandated. The legal rights of the accused is guaranteed set in the level of national, regional or international, and with the aim of adopting a decision in a fair and judicial errors than to keep away from people who are offence, in order to be exposed to. Including these rights can be charge with its reasons, the right to have a lawyer, the right to silence, a prohibition of delay and procrastination in charge after arrest or summons, the right note, the right to health in statements against torture questioned. Meanwhile, In the system of criminal procedure if what legislator to some of the aforementioned rights in its rules on match point but the hearing system in Turkey, including in particular anticipating the unconditional right to have a lawyer, the right to prohibit the delay in charges and the right to an annulment of the flawed investigation and classified problems. Obviously fix the defects and its assignment to investigation compliance under the law is just and fair hearing flow will be extremely helpful.
\end{abstract}

Keywords: preliminary investigation, the accused defense right, charges, the accused

\section{Introduction}

The right to defense of the accused is the most sacred of human rights that guarantees the rights and freedoms of the individual. In fact, identifying the right defense to defend the community against the violation of individual rights and freedoms, the requirement is undeniable, and in a deep and wide concept of judicial reasoning and expression, it hired using the legal tools in order to resolve charges of judicial authorities to people with relation. Maintain order and to defend the rights of society everywhere with the protection of the rights of the accused and the Defense limited and balanced the interests of the community should not lead to ignoring the rights of the defendants. When an individual is exposed to the charge? Investigation on the charge due to the steps of his individual rights may be limited or stripping and to avoid undue violate the human rights and legal rights and keep him, and outlines the basic rights of the accused in legal texts necessary and essential practice. The stage of the preliminary investigation of the most elementary steps facing the defendant with criminal justice and criminal procedure the first stone monument which is the role of the main players of judicial enforcers. The main challenge posed at this point it is a defendant at this stage of what is legal. Do you have the right to defend his silence at this point is recognized? Are required to declare the right of judicial enforcers the silence to be charged? (Hashemi; 2013)

Preliminary investigation on the rights of the accused in the process of defense as one of the most important principles of a fair trial, in international and regional documents as well as the rules and regulations of the countries and will be supported by the fact that right in the Statute of the International Criminal Court is also taken into consideration and including the assumption of innocence (the principle of presumed innocence), the right to silence, the right to have a lawyer, advocate, a ban on forced confession and. For the defendant in the 
proceedings to a fair trial on charges he has the right to set a fair arbitration is filed in order to reassure people in the form of illegal and unfair punishment, they will be met and their rights (Beig Zadeh; 2009).

In this study of how the protection of the accused at the stage of preliminary investigation in Iran and Turkey and human rights laws studied, but the start of this debate depends on another question to find the answer and it is "therefore" the defense of the accused. In other words, the probability that the accused is an offence of his area and acceptable reasons there are also in this area and why should he in the process of criminal proceedings and the rights of defense and the guarantees for she considered? This is a discussion of items that we want to move it to this thesis and another point to look at why the defendant is cynical? Besides, while explaining the importance of the stage of the preliminary investigation, a comparison between the legal system and preliminary investigation on the Turkish standards and criterion is that, at this stage can be adhered to for our legal system and the many ups and downs during the current situation is also with the existence of the basic principles of acceptance and fair hearing in the constitutional law of the Islamic Republic of Iran, such as the criminal procedure law and the right of access to a lawyer, with the exception of cases Exceptions and accepting the principle of the right of the accused to communicate and weapons draws partly to fix defects and defect cases and expressing it, the rights of the defense, the accused and punished for illegal and unfair.

Charged interest on the side of the necessity of preserving the interests of the community, for the purpose of criminal law is important, link the interests of the defense of society without being dependent on ignoring the rights of the accused and the provisions of the code of criminal procedure are to disposition of the offender be able to escape from the clutches of Justice, or that the past caught up to innocence makes punishment unjustly (Akhoondi; 2001).

\section{Definition of Preliminary Investigation}

Part of it is that all actions or actions prior to the trial and the proceedings in the Court or authorities with the investigation because criminal proceedings in the various stages of the criminal procedure, which consists of the discovery phase of the crime, the prosecution stage, the stage of investigation, the stage and the stage of issuing execution on the other hand, usually in the structure of the judicial authority, a prosecutor or by the name of attorney that exists under the law is part of the investigation on the crime of responsibility He will be laid off. Thus, the purpose of the preliminary investigation to comment about the reasons for the charge and prepare the file for the proceeding stage. The general principle governing the investigation that in most legal systems, the principle of the separation of authority accepted the pursuit of investigation is so preliminary investigation about the reasons for a charge, the accused by the same initiator where the prosecution has given nothing, based on this principle, it is necessary, the objectivity of the judge is up among the investigation community representative (Attorney) and who is said to be based on public order is stirred (a defendant) to impartial arbitration. Accordingly, today accepted that an accused upon the prosecution called a Prosecutor as the representative of the community, and investigation and comment about the reasons for the charge the defendant upon an examining magistrate will have to put the name of the judiciary system (Khaleghi; 2008).

\section{Defendants" Rights in Iran and Turkey's Legal System}

\subsection{The Rights of the People in Custody from the Point of Informing Them}

According to article 50 of the law of criminal procedure: "the person under consideration can be by phone or by any means possible, family members or acquaintances of their being under the supervision of enforcers are also aware of the necessary assistance in this regard to action, unless based on the necessity to recognize that the person should be under the supervision of such a right. In this case, you must obtain the appropriate command far to inform the judicial authority."

Article 52: "whenever the accused was put under the supervision of the justice enforcers, have required the rights stipulated in this law, in the case of a person under the supervision of the accused and to communicate in written form in his possession and receipt and attach the file."

The person arrested must be informed immediately of the reasons for his arrest. As well as of their rights in the judicial and family custodial authorities with conscious. These rights including the right to use legal advisor. Defendants must also be immediately aware of the charges against her. This is to inform the accused of this by allowing to know about his arrest as he fights the plan or allow your argument has got the basic and fundamental to the preparation.

\subsection{The Right for Knowing the Charge and Its Reason}

According to article 53 of the law of criminal procedure: "the person's statements have required enforcers of Justice under the supervision of, the cause being monitored, the start date and time, duration of the interrogation, 
the duration of the break between the two interrogations and the date and time that the person is introduced with the judge on IELTS and statement to make it her signature or fingerprint. Enforcers also have these start and end date and time being under certain records in the Office. "The rights of the defendants in detention is immediately arrested and the reasons for their charges. The most important immediate effect to inform the accused, about the reasons for the detention or bans that lets him about the legality of their detention or lack of conflict. This information should be provided about the reasons for the detention of the accused minor provided, accurate and, in such a way that certain of the legal principles or describe its true.

In the Turkish legal system, the right in paragraph (a) and (b) the criminal procedure law, article 147 to this description mentioned that a complete specification of the accused or the suspect recorded and properly it can be asked and the person appointed to be the crime described in article 145 of the same law, and added that the invitation to carry out the written description in the form of and because it explicitly States.

In the Iranian legal system, the right in principle thirty-second of the Constitution as follows: In the event of arrest, the subject of the charge must be referring to the reasons for documented immediately "to the issue and be communicated to the accused and maximum within twenty-four hours to the competent judicial preliminary file post trial arrangements and provide as soon as possible," as well as article 5 of the criminal procedure law stipulates that the accused must as soon as possible, of the issue and the reasons for the accusation to be aware of the related. And in article 46 of the same law States that if the accused in crimes evident, maintenance to complete essential investigation, enforcers should be the subject of the charge and the reasons for it are immediately communicated to the accused in writing and to communicate and to make legal decisions for much immediate notice to the Prosecutor.

\subsection{Informing the Detained about Their Rights}

According to article 46 of the law of criminal procedure: "enforcers of justice are the result of your actions to inform the Prosecutor. If the Attorney doesn't know enough to perform actions, can complement it. In this case, enforcers should be according to the order of the Prosecutor's investigations and legal actions for the discovery of the crime and the completion of the investigation to action, but the accused cannot be monitored. If the accused in crimes evident, maintenance to complete essential investigation, enforcers should be the subject of the charge and the reasons for it are immediately communicated to the accused in writing and to communicate and to make legal decisions for much immediate notice to the Prosecutor. However, enforcers cannot be more than twenty-four hours under the supervision of the defendant. "essentially, the condition of having exercised any right to notice, although it is right.

The defendants also are no exception. Whenever a person accused of committing a crime, but by virtue of one of the judicial control of appointments, find relief from their detention, can refer to a lawyer or a legal adviser from the preliminary investigation stage rights or tending to be aware of, but the person in detention is not entitled to this practically, and therefore must be linked with the arrest of the accused when the authorities are aware of their legal rights to her. In article 121 of the law of criminal procedure referred to be that enforcers should be the subject of the charge and the reasons for it are immediately communicated to the accused in writing.

\subsection{Informing the Detained about the Right to Have a Lawyer}

"Having a lawyer at all stages of the dispute of rights for criminal justice to. The accused has the right to attend the first examining magistrate after his lawyer freely with dialogue and consultation, even in the case that the examining magistrate, the accused could be banned, this prohibition does not apply to accused defense attorney" (Ashoori; 1997). One of the most important rights that the person arrested is in need of knowing it, choosing the right lawyer at the preliminary investigation stage. "The announcement of this right, to allow a person who uses information from a legal advisor, defense procurement, see fit. Moreover, in order to fix the import charges (Taha \& Ashrafi; 2007). The principle of the fifth and the Iranian Constitution stipulates: "in all courts the parties who have the right to choose their own attorney and if you do not have the ability to select a delegate must be provided by an attorney to determine the facilities for them."

The most important new developments in the law of criminal procedure creationist of Iran is that, as soon as the person charged was under consideration as it can "request a meeting with the lawyer. In this meeting, which should lead to an hour before, it is necessary to be careful investigation and the confidentiality of the talks and in the end an attorney can be tips that the supplier of his rights in writing, to be inserted in the file (Article 48, Iranian Legal Procedures). However, if the person due to commit one of the crimes or offences against the security of the country organized, theft, drugs and crimes pursuant to the punishment, or penalty, stripping of life, life imprisonment, mutilation and crimes against physical integrity, with the amount of intentional thirds Diego full or over it, under the supervision of lawyers, litigants, their lawyers or between lawyers for the Justice 
Department official who approved the judiciary Chief to be elected (Article 48, Iranian Legal Procedure). This article is against dignity of the lawyer because:

Firstly: lawyers for off by noble spiritual and advocacy within the official formalities obliged to swear the husband (the inauguration). Therefore, in contrast to the religious and legal behavior based on generalized to all their lawyers, is because it seems to be a difference between the inaugural judges and lawyers that in order to respect the laws of blasphemy and Islamic society and the preservation of the property and the lives of multitudes of people, and other people will be held on the basis of the law, does not exist.

Secondly: the lawyers and their morally, religiously, legally adhere to privacy principles such professional society (in security) and the people they know and ask for even attorneys we limit in these areas with the philosophy of the revolution and the status of implementation of the warranty for the disclosure of secrets others in conflict is evident and that the Mission of the Criminal Affairs lawyers, from charities to uncover the truth and help the judicial system in this field. In fact, engagement can be judges and lawyers in a manner favorable to the criminal justice community, victims and even provide views to be culprits.

In Turkish legal system, the right to full and fair expression of the face. In paragraph 3 of article 149 of the Turkish penal law prescribed ritual magistrate "in each of the stages of investigation and trial lawyers can meet with the suspect or accused and the relationship. And he's legal assistance and this right cannot be restricted ". While in the Iranian legal system as previously mentioned, the exclusions and the prerequisite that brought a kind of limiting the rights of the accused and the right to choose a lawyer."

As well as in part (c) of article 147 of the Turkish criminal procedure law stipulates: "the right to choose a lawyer and use to help her in her trial be communicated. In the event that the person is not able to choose a lawyer and will not use it or from his lawyer for a law firm Office. " The defendant has no duty to declare the facts in judicial authorities, but the public prosecution authority of the dispute (the Prosecutor) is required in the case of persons charged, collect enough reasons against them and cannot on behalf of their dispute (the accused) have the expectation of cooperation and he is obliged to state the facts. Also because of the silence of the accused, with no items cannot be added to his file, in line with the principle of presumed innocence, should not be silent as a context against the accused and in proof of his charge. The right (the silence) is also one of the basic and fundamental rights of the accused is aware of the existence of such a right off her.

\subsection{The Right to Connect with the Outside}

At the stage of preliminary investigation must have the possibility to communicate with arrested person out there. The prohibition of torture and solitary detention and prohibition of forced sterilization of medical tests such as superior to him without his consent during the detention. In the country in which the formalities are not adhered to fair proceedings of the prisoners, especially the people who are supposed to be executed, such as laboratory rats (Najafi Abrand Abadi; 2007).

People who are detained have the right to communicate immediately with your family, for your requested appointment with the lawyer requested and doctor (with the exception of dental practitioner) examination of them. Also, if the defendant is a foreign embassy officials with right to your home or your respective consulate in direct contact. If an immigrant is by agents of the international organizations concerned. experience has shown that it can be accused of communicating with the outside world and constitutes a guarantee of custody as fundamental to prevent human rights violations and acts of violence against the defendant named because whenever the defendant is able to easily meet your treating by a doctor or non-governmental organizations to be able to meet the accused, due to the ease of data transfer out of the prison, and the possibility of torture Physical problems are reduced to a minimum.

But sometimes, in pursuit of some of the crimes and the importance of the delay on the social order of the severity is more like the transit of drugs, terrorism and other crimes, where necessary on the other and the guarantee of public order could become a forbidden command $r$ official accused of collusion with the defendant while the potential collaborators and the Elimination of works and the reasons for the crime of misdemeanor dependent to discover faster. Also, considering that his lawyer could accuse of being denied the right to defense by the defendant undue harm, therefore, the ban does not include meeting the accused lawyer (Shahbazi; 2007).

Communication with the outside world since the arrest of the accused to one the following forms:

A. Associated with all people and accepting them in jail (ban, banned from meeting the person)

B. Notifying a person banned family and the possibility of his arrest to his family 
C. Direct from the doctor treating the personal relationship) (non-governmental) and her relationship with the accused at any time he deems essential to recognize and or family

D. The accused has the right, if external) communication meeting with a representative of their respective country and if the settler or under an international organization, the right to meet with a representative of that organization (Ashoori; 2011).

In article 50 of the law of criminal procedure with the right of Iran to gratuitously is expressed as follows: the person can be by phone or by any means possible, family members or acquaintances of their conscious being monitored. And enforcers also have the necessary assistance required in this respect to practice, unless based on the necessity to recognize that the person should be under the supervision of such a right. In this case, you must obtain the appropriate command far to inform the judicial authority. It is true that this right to the attention of the legislator and restraining to individual communication under circumstances making the atmosphere with the family he has but in this article it was better exception (of necessity) legislator Specifies to not misuse it.

Some other rights, such as to communicate with people outside the detention or direct contact with family members is also to be scattered in the prison regulations and other texts (such as the single paragraph of article 5 of the law respecting the legitimate freedoms and the rights of citizenship) stated that a detailed control tool for the exercise of these rights does not exist, therefore it is necessary that these cases are mentioned in the rules of clarity. In the Turkish legal system, these rights fully expressed. According to article 95, paragraph 1, of the law of criminal procedure in Turkey in the event of the arrest of the suspect to his family and close friends will be notified.

\subsection{The Necessity of Rational Detainment Period}

The investigation authority cannot be citing to the end investigation that has shunned any time you need to know to keep a person in custody and the investigation continues.

Determine the rules of what a reasonable deadline, to a time interval. Is a problem and this is the effective deadline include:

"The severity and the extent of the seriousness of the charges that have been imported to the individual, the nature and the extent of the possible punishment of the person and the amount of free and if the person accused of a dangerous or escape of the accused. To these factors must be the extent of the seriousness and complexity of the judicial authority and the specific features available in the investigation as well. As well as the behavior of the accused person, such as his lack of cooperation with the judicial authorities and the lack of attendance at the hearing could be prolonging the investigation and accountability to help arrest prolongation, and at the same time also a reasonable deadline into account."

European Commission of human rights in terms of disrupting the numerous decisions on this has been that the "reasonable deadline" vague concept that just in terms of the specific situation of each case must be investigated. The following seven factor are mentioned as the Commission's reasonable duration for the arrest of consideration: "the duration of arrest", "detention for offences in connection with the type of material and spiritual artifacts", "the detention of the accused", "compared to the behavior of the accused", "the complexity of the supervisor to Investigation Foundation", "the way of the preliminary investigation into action" and "judicial conduct in connection with the examination claim arrest jaw" (Ashoori et.al. 2002).

In the Iranian legal system, the concept of "reasonable deadline" clearly about the judgment of the legislator and law of criminal procedure in article 242 of Iran mentioned as follows: whenever the subject of paragraphs in the crime, a crime punishable by virtue of life-stripping-b-crimes pursuant to life imprisonment-c-penalty offences by virtue of intentional crimes against the amputation and physical integrity, the one with the amount of blood money full or over it-c-an additional penalty offences by virtue of four degrees and above-c-political offences and press, article ( 302) of this law and other crimes two months to up to a month due to the issuance of the supply going to stay in custody, accused of charges against him and leading up to the final decision on the Prosecutors Office, examining magistrate shall be obligated to put supply or discount of the jaw. If causes legitimate to put survival exist, with the causes, according to the defendant, and the preservation of the notification and the defendant can be of this decision within 10 days of the date of notification to the competent court to protest.

Put the jaw or discount without having to agree to the Prosecutor and the Prosecutor probe the supply must be verified. In addition, in the case of the Prosecutor's opposition to the settlement, with a competent court discount, or retain temporary detention must be verified and the Prosecutor in the case of the Prosecutor's opposition to the settlement with the competent court. Whenever the accused continue to be detained. The provisions of the SIC, 
per item, per a month or every two months to be announced. Anyway, for the arrest of the defendant shall be punished by imprisonment of at least the prescribed in the law for the crime of rape and that in any case the punishment of crime pursuant to the stripping life for temporary detention of two years and the other crimes of does not exceed one year.

Note 1: the maximum period of detention, the curriculum includes the total appointments and the Prosecutors Office issued in court. And other appointments leading up to the arrest of the accused is included.

According to the article above, it must be said that being a reasonable deadline for the arrest of legislator considered and on the other hand, however, with the adoption of this law, the examining magistrate has required the implementation of this law, and in fact involves the effort to limit the duration of detention.

In the Turkish legal system as it is emphasized in article 102 referred to is as follows:

1) The period of detention of the criminal offences that are not among the crimes the Court matters, one year, but this time in acute conditions can be expandable up to six months

2) The period of heavy crimes two years detention. This time, if necessary, could be extended up to a year to be expandable and totaling three years

3) The increase in the duration of imprisonment after holding the meeting of the courts by the Attorney

In addition, article 103 as well as follows: the public prosecutor can release the suspect or convicted and the Court of requests. His or her lawyer, and condemned also can apply. In addition, if for some reason the Prosecutor of the Republic, the term of imprisonment in the meanwhile the lack of necessity to provide custody, sentenced to be acquitted and if that need is not on the retrial he will be free.

In article 104 of the law of criminal procedure of Turkey at each stage of the investigation, the defendant can request the innocence, then the result in both systems to a reasonable deadline, as well as being objectionable referenced with the difference that in the Iranian legal system if he charges leading up to a final decision on the Prosecutors Office, examining magistrate shall be obligated to supply the jaw or discount.

\section{Conclusion}

The preliminary research stage can be the most important stage of the criminal process because the Foundation knew a criminal file at this stage takes shape and the handle to the next, always pay attention to the results of this stage. Pay attention to the basic two-point at this stage is essential: the first being to preserve and restore public order crime, corrupt officials to chase and enforcers should spend all their efforts uncover the truth and create the appropriate background for the implementation of Justice. In order to avoid the real culprits escape or relieve the reasons and similar cases, this step should be specific and sometimes sensitivity to public and non-confidential basis. The second and more important point is that, at this stage, it is still not evident under the chase and charge person so should be in light of the rule of assumption of innocence and step under the pretext of maintaining public order and the possibility of stripping the rights of blunt personal freedom is not provided. This causes the preliminary research stage, of the importance and sensitivity of the art and is certain that it is legislator and the interests of Justice to allow the two above-mentioned twin consideration.

In the Iranian legal system with the formulation of the new law of criminal procedure related to the defects, and preliminary research of the vacuum are largely removed. A course in basic laws and principles of a fair trial in Turkey in the preliminary research in much the same with the Iranian legal system, including the principle of the preliminary research stage speed is that both systems are well prepared and have the required enforcers as soon as possible and at the time that the judicial authority can determine the relative commands to perform and complete action on file, so what any cause not run command or file Not completed owing to the competent judicial authority, the relevant post. Another point being reasonable necessity for the present and immediate arrest of the accused with a judge. This is in the Iranian legal system and in the Turkish legal system it is that the defendant must be in the maximum period of 24 hours in front of the judge of the Court. However, the fundamental solution of this issue at the discretion of the judges and not the others. Including cases where the preliminary investigation stage pursuant to the prolongation, precautionary appointment failure for files is that they are concerned about the references of the inquiry takes place. The multiplicity and variety of the judges who issued daily by refraining, as they do not allow the process of doing it for the sake of down. Moreover, the other one of the important features of the preliminary investigation it is non-public, that is, that the release of the accused on the charge of news and public opinion pressure and in most legal systems of the world this is accepted.

Another point is the right of the accused to the charges and the presence of a lawyer in the preliminary 
investigation, which is in both systems, well to the right of the accused to the charges has been mentioned, namely that the accused to the crime described the related of their rights as well. in the legal system of Turkey, the right to choose a lawyer and use to help her in her trial will be communicated to and if they are able to choose a lawyer and Or will not use it on behalf of his law office a lawyer to determine that this is consistent with the principles of the fair legal procedure. But in the Iranian legal system, the legislator has mentioned that some kind of gratuitously, defects in charge rights. Of course, the new law compared to the past, there has been a transformation, but it is not right to fully comply. Another point that measures such as having the right to silence and the lack of having announced he is responding and prohibit the right to delay and procrastination in the charge to the accused and the right to defense and the right to request compensation opportunities.

\section{References}

Akhoondi, M. (2001). Legal Procedure Regulations (9th ed., Vol. 1, pp. 6-58). Tehran: Publications of the Ministry of Islamic Culture and Propagation.

Ashoori, M. et al. (2002). Human Rights: Definition of equality and fairness (1st ed., pp. 10-56). Tehran: Publication of the Faculty of Law and Political Sciences of Tehran University.

Beig Zadeh, J. (2009). Cases of Neglecting Fair Procedures in Iranan Legal System and International Conventions. Thesis to Recieve MAster's Degree in Criminology. Shahid Beheshti.

Hashemi, M. (2003). Protection and Guarantees of Human Rights in Domestic and International Legal Systems. Journal of Legal Studies, 38,35-86.

Khaleghi, A. (2008). Penal Procedures (3rd ed.). Tehran: Ganje Danesh Pub.

Najafi, A., Abadi, B., \& Hussain, A. (2007/2008). Fair Procedure and Legal Justice Booklet. Faculty of Law. Masters Degree in Human Rights, 45-69

Penal Procedures. (2011). (10th ed., Vol. 1). Tehran: SAMT Pub. First Vol.

Penal, J. (1997). Collection of Papers (1st ed., pp. 1-23). Tehran: Ganje Danesh Pub.

Shahbazi, M. (2007). Defendent's Rights in Penal Procedures in International Documents. Thesis to Receive Master's Degree in Criminology. Islamic Azad University at Central Tehran, 21-56.

Taha, F., \& Ashrafi, L. (2007). Fair Legal Procedures (1st ed.). Mizan Pub.

\section{Copyrights}

Copyright for this article is retained by the author(s), with first publication rights granted to the journal.

This is an open-access article distributed under the terms and conditions of the Creative Commons Attribution license (http://creativecommons.org/licenses/by/3.0/). 